\title{
EDITORIAL
}

\section{Taxes and Regulation}

\section{INTRODUCTION}

This Intertax issue is dedicated to taxes and regulation. It thus includes a series of articles to foster the debate on the role of regulation in taxes and tax policies, taking into account the ongoing disruption of national and international tax systems.

The underlying idea was to reflect on the role that taxation can play in achieving objectives that are not necessarily - or not primarily - related to the generation of public revenue. Although some aspects of regulatory taxation have already been analysed in great detail by economists and lawyers, some other aspects remain largely unstudied. Whereas the interaction between taxation and regulation is very often discussed from the perspective of regulatory taxes, we have deliberately welcomed contributions that approach this topic from a broader perspective.

Hence, in the articles published in this issue, the term regulation is used in two different meanings and contexts. One of them refers to regulation as in international or regional (European Union) coordination with the purpose of reducing tax competition (either harmful or not). Regulation, in this sense, generally begins from the assumption that tax sovereignty is no longer sufficient or even valid. ${ }^{1}$ Such a loss of tax sovereignty at the domestic level can be explained by the impact that some domestic tax measures provokes on other states' tax systems. The International Monetary Fund (IMF) has described this impact by reference to the concept of 'spillovers'. ${ }^{2}$

The other meaning refers to regulation as in regulatory taxes, stricto sensu, i.e. those tax measures that are enacted to achieve non-fiscal goals, either tax subsidies aimed at stimulating desirable behaviours and activities or corrective taxes intending to internalize negative externalities and discourage undesirable behaviour (so-called 'Pigouvian taxes'). ${ }^{3}$ The line-up of articles in this issue begins with the two articles that address regulatory taxes stricto sensu. ${ }^{4}$

\section{Regulation as international or REGIONAL COORDINATION}

When regulation is understood by reference to the need for international or regional coordination, States are seen as market players ${ }^{5}$ for which tax policy must be regulated by a supranational entity such as the Council of the European Union or by an arbitrator such as the G20 or the OECD that might not have democratic legitimacy.

This lack of democratic legitimacy implies that there is ambiguity regarding what interests are being pursued. ${ }^{6}$ In this respect, the articles published in this issue appear to assume that regulation (as in 'coordination') protects sovereignty itself or the survival of the State as the entity that collects taxes and redistributes wealth. Taxes and redistribution would then be regarded as the major purposes to be pursued by a State, every State, including those that do not (yet) appear to consider redistribution as one of the key objectives of the tax system.

Those articles also show that regulation could be either merely procedural - if only limited to approve the rules of

\section{Notes}

C. Garbarino, How Countervailing Measures Could Be Used to Limit Strategic Tax Competition. An International Overview, 48(4) Intertax (2020), point 3; L. Ates, Positive Spillovers in International Corporate Taxation and the European Union, 48(4) Intertax (2020); S. Gadžo \& Š. Jozipović, International Corporate Tax Regime Post-BEPS: A Regulatory Perspective, 48(4) Intertax (2020)

IMF, Spillovers in International Corporate Taxation, IMF Policy Paper, 6 (2014), https://www.imf.org/external/np/pp/eng/2014/050914.pdf (accessed 5 Feb. 2020); also cited by Ates, supra n. 1, point 1

J. Hey, Effectiveness of Regulatory Taxes: Control Through Proceedings v. Judicial Control - a German Constitutional Perspective, 48(4) Intertax (2020); J. E. Milne \& M. Villar, Renewable Electricity and Tax Expenditures: Lessons from Two Countries, 48(4) Intertax (2020).

Supra n. 3

T. Dagan, The Marketization of Tax Sovereignty (2017), http://dx.doi.org/10.2139/ssrn.2953220 (accessed 5 Feb. 2020); T. Dagan, International Tax Policy: Between Competition and Cooperation (Cambridge University Press 2018).

6 A. P. Dourado, Justiça Tributária Internacional, 37(41) Revista Direito Tributário Atual 457-487 (2019); A. Pirlot, The Vagueness of Tax Fairness, a Discursive Analysis and a Critique of the Commission's Fair Tax Agenda, 48(4) Intertax (2020). 
the game, such as transparency measures ${ }^{7}$ - or also interfere in the design of corporate income taxes, including the tax base and tax rate (e.g. if a minimum tax rate were to be adopted). ${ }^{8}$

\section{Procedural regulation}

Ates, Harari and Meinzer focus on the need for greater tax transparency and implementation of anti-avoidance measures in order to decrease negative externalities resulting from domestic tax policies. The authors concentrate on the indicators for 'transparency' and 'anti-avoidance' under the Corporate Tax Haven Index (CTHI) which is an index that conducts a legal analysis of domestic corporate income tax systems and ranks them according to their alleged contribution to the 'race to the bottom' of corporate tax systems. Departing from the CTHI, the authors critically examine the positive international corporate tax spillover pathways in the European Union Member States' legal systems and compare them with the rest of the world. The authors conclude that there is room for improvement both in respect of transparency and antiavoidance rules.

\section{COORDINATION OF TAX BASES OR/AND RATES}

In comparison with the approach aimed at more transparency and anti-avoidance measures, the approach envisaging coordination of substantive elements of corporate tax systems, such as the base or the tax rate, assume that such coordination is in the interest of all States. To verify such an assumption would require that coordination measures were adopted by an international body with democratic legitimacy under democratic procedures that are similar to those that characterize discussion and voting procedures in national parliaments (with consent, dissent and approval by a majority of votes). Only then could coordination possibly benefit all States despite the significant divergences that characterize their interests. The articles from Carlo Garbarino, ${ }^{9}$ Stjepan Gadžo/Šime Jozipović ${ }^{10}$ and Irma Mosquera ${ }^{11}$ indeed demonstrate how divergent the interests of residence and source or market countries can be.

Garbarino assumes that regulatory measures are legitimate for countering strategic tax competition that leads to negative interference in other States. Moreover, he supports the adoption of 'countervailing' measures against States that violate tax coordination measures. A key point of his proposal is that these measures would be applied to States and not by States to their citizens. Governments organized under (future) multilateral treaties would be entitled to request the adoption of 'countervailing measures' against other governments with the purpose of offsetting 'some perceived harm or negative interference arising from certain national tax strategies'. Coordination and countervailing measures applied to the transgressing States could be perceived as regulatory measures because the system would primarily be aimed at deterring strategic tax competition and not at raising revenue.

Garbarino seems to assume that the major interests at stake are those of the ultimate parent company in the ultimate residence country. Therefore, in order to avoid 'corporate flights out of ultimate residence countries', he proposes the enforcement of exit taxes. Finally, Garbarino proposes allocating the revenue generated by the imposition of countervailing measures to 'a special-purpose fund' that could be used to compensate companies and communities that are negatively affected by the targeted tax competition.

Gadžo/Jozipović and Mosquera's articles contrast with Garbarino's analysis. Their articles illustrate that the BEPS Project and other proposals on international tax coordination do not result in the same judgements when considered from the perspective of an OECD or a developing country.

Gadžo/Jozipović understand 'regulatory perspective ... as the capacity of rules of international tax law to affect the behaviour of both corporate taxpayers in arranging their cross-border activities and the States in designing their CIT systems'. The authors contend that cooperation between States is necessary in the current context of tax competition and also praise the Base Erosion and Profit Splitting (BEPS) Project and its regulatory role of tax avoidance. They further assess the Global anti-base erosion proposal (GLOBE) under Pillar $2^{12}$ as a consensus-based and longterm solution to tax challenges raised by globalization.

By contrast, Mosquera contends that BEPS Action 5 is not the correct regulatory framework to evaluate tax incentives (preferential tax regimes) for developing countries as it allegedly damages these countries' interests from both procedural and substantive perspectives. Because of

\section{Notes}

As handled by Ates, supra n. 1; See also Pirlot, supra n. 5.

Garbarino, supra n. 1; Gadžo \& Jozipović, supra n. 1.

Garbarino, supra n. 1.

10 Gadžo \& Jozipović, supra n. 1.

I. J. Mosquera Valderrama, Regulatory Framework for Tax Incentives in Developing Countries After BEPS Action 5, 48(4) Intertax (2020).

12 OECD, Programme of Work to Develop a Consensus Solution to the Tax Challenges Arising from the Digitalisation of the Economy, OECD/G20 Inclusive Framework on BEPS (OECD Publishing 2019). 
its ambiguity, Action 5 brings uncertainty and increases compliance costs to developing countries, preventing them from enacting legitimate tax incentives. Therefore, Mosquera proposes several criteria to enhance transparency with regard to the manner in which the Forum on Harmful Tax Practices (FTHP) conducts its review of the existing preferential regimes. ${ }^{13}$

\section{Regulation and tax fairness}

The aforementioned approaches seem to assume that corporate taxes on profit (net profit with some elements of presumptive taxation) are the right instruments to not only protect state tax sovereignty but also to defend equity between/among them. Coordination is indeed often presented as an important instrument for achieving 'tax fairness'.

Pirlot analyses this claim in the European context. In her article, she contends that the European Commission's traditional 'market-oriented' approach has been recently complemented by a 'fair tax agenda'. Although this approach began in 2015 in the context of the BEPS Project, the European Union has not traditionally performed budgetary and redistributive functions. Pirlot's article intends to demonstrate that the European Commission does not take tax fairness seriously in terms of substantive fairness. At most, tax harmonization is carried out as a 'protective shield' against tax competition and tax avoidance.

A similar conclusion could be drawn in the international context. Both in a European and in an international setting, the substantive meaning to be given to tax fairness is likely to remain ambiguous unless all states' interests are recognized and taken into account on an equal footing. This also implies that, although negative spillovers are a fact and have to be acknowledged, the idea that the interests of residence countries are those that deserve protection has no democratic or legitimacy grounds.

\section{Regulatory taxes}

In addition to articles on tax and regulation as in coordination, this issue of Intertax also includes two articles that address the more traditional understanding that characterizes the interaction between taxes and regulatory objectives. In comparison to the other articles published in this issue that examine tax systems in a European or international context, these two articles focus on the design and features of domestic tax systems. Each of these articles sheds new light on the characteristics and the role of regulatory tax measures sensu stricto.
Hey's article draws attention to the need for a more efficient evaluation of regulatory taxes. In her opinion, the effectiveness of regulatory taxes is a key element for their justification. Though corrective taxes can help raise revenue, they should not be justified on regulatory grounds if they are ineffective (or become ineffective). Regarding ineffective tax incentives, they are even less justifiable given their cost and negative effect on public revenue. Based on these observations, Hey emphasizes the benefits of both an ex ante and ex post monitoring of the effects of regulatory taxes.

Milne and Villar's contribution nicely complements Hey's analysis by discussing the specific case of tax expenditures that are utilized to support the use and production of renewable electricity. By means of a comparative analysis between the United States and Spain, the two authors draw attention to the factors that can influence the decisions of policymakers when considering the use of tax expenditures. Besides the need to assess the cost-effectiveness of the measure at stake, Milne and Villar show that the institutional context might affect the design of tax incentives as well as other market-based instruments.

\section{Concluding Remarks}

Taxes and tax policy have always had regulatory effects. Whereas regulatory taxes are primarily aimed at influencing behaviours or correcting market failure, taxes that do not qualify as regulatory taxes sensu stricto can also function as regulatory instruments that are exploited to correct the failures of the international tax system. The goal of this issue is to draw Intertax readers' attention to these two regulatory aspects of taxes and tax policies.

Though the question of the interaction between taxes and regulations might appear to be overly theoretical, the analyses provided by all of the authors who contributed to this issue substantiate that this question is, in fact, very practical. The articles published in this issue are all linked to tax policy issues that are high on the political agenda. Environmental taxes and market-based instruments are regularly discussed as a way to tackle climate change. For example, Ursula von der Leyen, the new president of the European Commission, has recently called for the adoption of 'border carbon taxes'. If implemented, the effectiveness of these carbon taxes will need to be critically assessed in order to ensure that they help mitigate climate change.

Similarly, the entire digital tax debate could be analysed as a regulatory debate in which taxes are being used to regulate economic relationships and level the playing field between the digitalized sectors (allegedly favoured by the current legal system) and the rest of the economy. However, the digital tax debate goes beyond the use of

\section{Notes}

13 Mosquera Valderrama, supra n. 11 
regulatory taxes sensu stricto in that it raises the question as to the need for coordination at the European Union and OECD levels. As many authors in this issue have shown, there is neither a simple nor a single answer to this question.

New questions on taxes and regulations are likely to emerge in the future. The UN 2030 Sustainable Development Agenda clearly indicates that taxes are to play a key role in the implementation of the seventeen regulatory goals - referred to as the 'Sustainable Development Goals' (SDGs) - that it includes. These goals are broad and ambitious, going from ending poverty (SDG 1) to ensuring access to affordable and sustainable energy (SDG 7) and achieving gender equality (SDG 5). Aside from the European Union and the OECD, it is striking to note that the United Nations also perceives tax measures as regulatory and as coordination instruments to achieve its 2030 Agenda.

Ana Paula Dourado

Editor-in-Chief

Email: anadourado@fd.ulisboa.pt.

Alice Pirlot

Said Business School, Oxford University

Email: Alice.Pirlot@sbs.ox.ac.uk. 